\title{
Predicting outflow induced by moraine failure in glacial lakes: the Lake Palcacocha case from an uncertainty perspective
}

\author{
D. S. Rivas, M. A. Somos-Valenzuela, B. R. Hodges, and D. C. McKinney \\ Center for Research in Water Resources, University of Texas at Austin, Austin, Texas, USA \\ Correspondence to: D. McKinney (daene@aol.com)
}

Received: 8 August 2014 - Published in Nat. Hazards Earth Syst. Sci. Discuss.: 19 September 2014

Revised: 22 April 2015 - Accepted: 10 May 2015 - Published: 9 June 2015

\begin{abstract}
Moraine dam collapse is one of the causes of glacial lake outburst floods. Available models seek to predict both moraine breach formation and lake outflow. The models depend on hydraulic, erosion, and geotechnical parameters that are mostly unknown or uncertain. This paper estimates the outflow hydrograph caused by a potential erosive collapse of the moraine dam of Lake Palcacocha in Peru and quantifies the uncertainty of the results. The overall aim is to provide a simple yet hydraulically robust approach for calculating the expected outflow hydrographs that is useful for risk assessment studies. To estimate the peak outflow and failure time of the hydrograph, we assessed several available empirical equations based on lake and moraine geometries; each equation has defined confidence intervals for peak flow predictions. Complete outflow hydrographs for each peak flow condition were modeled using a hydraulic simulation model calibrated to match the peak flows estimated with the empirical equations. Failure time and peak flow differences between the simulations, and the corresponding empirical equations were used as error parameters. Along with an expected hydrograph, lower and upper bound hydrographs were calculated for Lake Palcacocha, representing the confidence interval of the results. The approach has several advantages: first, it is simple and robust. Second, it evaluates the capability of empirical equations to reproduce the conditions of the lake and moraine dam. Third, this approach accounts for uncertainty in the hydrographs estimations, which makes it appropriate for risk management studies.
\end{abstract}

\section{Introduction}

Flood risk downstream of a natural dam depends on the capability of the dam to hold the impounded water. That capability can be exceeded due to overtopping wave events; catastrophic collapse of the dam induced by either structural failure or accelerating erosive processes; or by a successive combination of both phenomena in a two-phase outburst flood (Kershaw et al., 2005). In moraine-dammed glacial lakes, both kinds of failure can occur. Knowing a priori the hydrograph for a potential glacial lake outburst flood (GLOF) would be useful for risk analysis and mitigation, but it is not clear the level of detail required to have a reasonable approximation. In this paper we focus on estimating the hydrograph for potential erosive failure of a moraine-dammed glacial lake.

The erosive physical phenomena that drive earth dam breaches are not fully understood. The complex interaction between soil and fluid dynamics that governs the dam erosion process presents a research challenge. Furthermore, lack of data, difficulties of taking measurements in remote areas, and the increasing impact of climate change add more uncertainty to the physical parameters involved in predicting natural dam failures. Wherever human lives and economic damages are at risk because of a GLOF, predicting the failure of a moraine dam is relevant. The history of glacier-related disasters shows that, independent of infrastructure and economic damages, devastating events have taken nearly 30000 lives in the Cordillera Blanca region in Peru since 1941, many of them from GLOFs (Carey, 2005). Underestimating future dam failures could result in ineffective mitigation actions, exposing people to severe danger. On the other hand, overestimating their magnitude might create an atmosphere of fear in communities that, otherwise, also depend on water resources 
coming from glaciers. Consequently, uncertainty surrounds moraine failure estimation because of the physical nature of moraines and because of the range of dangers they create. Accounting for this uncertainty in predictive models may inform broader flood risk analyses and lead to improved mitigation actions.

Two types of methods have been developed previously to predict breach development across earthen dams and the resulting outflow hydrographs. The first type involves $d e-$ terministic models that attempt to describe the governing physics of the problem and apply sediment transport or energy dissipation models (Temple et al., 2005; Hanson et al., 2005; Visser et al., 2010; Westoby et al., 2014). These models are focused on engineered earthen dams. Their utility is limited by our relatively poor understanding of the hydro-erosive phenomena for cohesive soils and because we typically lack the data necessary to characterize the hydraulic and geological properties of natural dams. The second type of method involves empirical models based on recorded historical events of dam failures, which are used to estimate the characteristics of a dam breach and the resulting maximum peak flow. These methods use regression analysis to relate the peak outflow through the breach either to the depth or volume of water behind the dam, or the product of these variables (Pierce and Thornton, 2010; Wahl, 2010; Westoby et al., 2014). Empirical models are useful in cases where the characteristics of both impounded water volume and dam geometry are similar to those of the historical cases used to fit the model. This similarity requirement restricts their practical range of applications.

Deterministic models predict breach growth by considering hydrodynamic and sediment transport relationships inside coupled models that simulate dynamically varying weirs. These numerical models mostly use the Meyer-Peter and Müller (1948) sediment-transport relation to simulate forward erosion processes driving the breach shape and rate of growth. In contrast, field observations suggest that backward erosion, from the front end of the dam to the dam crest, is an important process in dam-breach formation; this backward erosion process is not addressed by sediment-transport models (Costa and Schuster, 1988; O'Connor et al., 2001; Temple et al., 2005). Furthermore, erosive breach mechanisms are inherently difficult to deterministically predict for glacial lake moraines since we often lack detailed geotechnical data. The accuracy of sediment transport models to simulate breach growth processes has not been thoroughly demonstrated, nor has their advantage over simple parameterization of average erosion rates on the basis of empirical data (Walder and O'Connor, 1997). For example, in the case of Lake Palcacocha considered below, uncertainty and lack of data limit the information about the damming moraine. It follows that deterministic models of erosive breaches are still research tools that are not yet suitable for risk analysis and mitigation studies.
Given the obstacles to developing and applying deterministic models, empirical models represent a reasonable alternative to assess potential dam-breach effects. However, to take advantage of their simplicity, we must assess their suitability. Although several authors propose empirical models and address uncertainty in dam-breach estimations (Wahl, 2004; Xu and Zhang, 2009; Peng and Zhang, 2012), less attention has been given to developing criteria to use in selecting one empirical model over another. Consequently, assessing whether a model fits the conditions of a particular dam site poses a challenge prior to effective model application.

Moraine dams become more susceptible to failure as (1) the width-to-height (DWH) ratio of the dam is small, (2) potential energy of the water in the lake is high, (3) freeboard is low, and (4) the moraine structure lacks internal cohesion. From the point of view of geomorphology (moraine volume, shape, and slope stability), moraines with low DWH ratios are more likely to fail (Wang et al., 2012); failure likelihood also increases due to hydraulic parameters of the lake (high potential energy) and poor geotechnical characteristics of the moraine (inner matrix composition).

Landslide dams, a particular case of natural dams, have received more attention than glacial moraine dams, producing, as a result, empirical estimation methods for peak outflow (Costa and Schuster, 1988; Walder and O'Connor, 1997; Wahl, 2004). The geologic processes behind the formation of each type of dam are different, but failure assessment methods might apply for both types due to common instability issues. Massive landslides commonly create dams after an almost instantaneous process of material deposition from rock and debris avalanches; rock and soil slumps; and debris, mud, or earth flows (Costa and Schuster, 1988; Nicoletti and Parise, 2002; Parise et al., 2003). In contrast, glacial moraine dams take geologic timescales to emerge. Despite these formation differences, the resulting dams (landslide or moraine) are similar in terms of the poorly consolidated and heterogeneous nature of the composing materials (Costa and Schuster, 1988). Although landslide dams are highly unstable, showing life spans even shorter than 1 year, better-graded debris flows favor longer longevities, with overtopping triggering most of their failures (Costa and Schuster, 1988; Nicoletti and Parise, 2002).

In comparison with landslide dams, moraine dams commonly possess steeper slopes (up to $40^{\circ}$ ) and smaller DWH ratios (0.1-0.2), more comparable to those of constructed dams (Clague and Evans, 2000; Costa and Schuster, 1988). Huggel et al. (2004) estimate that DWH ratios less than 1 lead to high susceptibility of failure for moraine dams in the Swiss Alps, while moraines with DWH ratios higher than 10 are not commonly expected to fail. Similar DWH ratios $(0.6<\mathrm{DWH}<1.7)$ represent high-susceptibility thresholds for Himalayan GLOF events (Wang et al., 2012).

Hydraulic simulation models such as the US National Weather Service Dam-Break Flood Forecasting Model (DAMBRK) (Fread, 1984) can complement the empirical 
breach equations. The fixed geometry and dynamic conditions of the dam-break problem (lake volume, breach shape, and failure time) limit the possible hydrographs resulting from a hypothetical dam breach. These hydrographs, which reflect the breach drainage capacity, are different for each possible setting of lake, dam, and breach geometry. The problem is that, even though the drainage capacity can be estimated in a simplified way using a hydraulic simulation model such as DAMBRK, these models lack capability to self-determine the breaching parameters. On the other hand, empirical equations do estimate breach development parameters, but they are based on historical observations not directly related to the problem of interest. Thus, empirical models are not capable of determining the hydraulic conveying capacity of the analyzed breach.

The principal contention of this paper is that a simple empirical method combined with hydraulic simulation can be used for estimating potential dam-break hydrographs for moraine-dammed glacial lakes, despite our admittedly limited knowledge of erosive processes leading to dam failure. The fundamental problem is that existing empirical models (which typically require only water depth and impounded volume as input parameters) only provide outputs of peak outflow and failure time; i.e., they cannot produce a hydrograph for risk planning and management. For this purpose, failure time, or breach formation time, is the time needed for complete development of the ultimate breach from the initial breakthrough at the crest to the end of significant lateral enlargement (Froehlich, 2008). In contrast, hydraulic simulation models can provide the full outflow hydrographs but require more extensive site-specific geometric data and calibration. Herein, we assess the application of empirical models as a calibration tool for hydraulic simulations generating a hydrograph for natural dam-break problems. The approach, applied to nine empirical dam-breach models, evaluates the case of a single natural glacial lake dam, estimating outflow hydrograph predictions and uncertainties (Wahl, 2004; Xu and Zhang, 2009; Peng and Zhang, 2012) to choose the most robust model. In addition, from the uncertainty bands of the empirical models we compute the upper and lower bound potential outflow hydrographs instead of a single expected instance, providing more robust results for flood risk management studies. We propose that the best empirical model for a given site produces results that best match those of hydraulic simulations. The site used here is Lake Palcacocha in Peru, a glacial lake impounded by a moraine dam, for which lower bound, predicted value, and upper bound outflow hydrographs are estimated considering the prediction intervals of the empirical breaching models.

\section{Study area}

The Cordillera Blanca, located approximately $180 \mathrm{~km}$ from the Peruvian coast where the Nazca plate dips below the
South American continental plate, is a relatively recent granodioritic batholithic intrusion into folded and faulted Mesozoic marine sediments (Young and Lipton, 2006; Mark, 2008; Sevinc, 2009). Large-scale uplift produced the current Cordillera Blanca and Cordillera Negra ranges, with the Callejón de Huaylas in between them forming the Rio Santa Basin. The Cojup Valley is a typical glacial valley with very strong recent fluvial remodeling and comprises various types of intrusive rocks, such as granites and granodiorites, with free rock faces above the talus deposits supplying the valley bottom with huge boulders (Vilímek et al., 2005).

Lake Palcacocha and similar glacial lakes have emerged as a consequence of deglaciation processes occurring in the Cordillera Blanca region in Peru (Figs. 1 and 2). Climate change in recent decades has accelerated glacier retreat and hence lake growth in this area (UGRH, 2010; Burns and Nolin, 2014). For instance, the volume of Lake Palcacocha increased from $0.5 \times 10^{6} \mathrm{~m}^{3}$ in 1947 to $17 \times 10^{6} \mathrm{~m}^{3}$ in 2009 , and a GLOF occurred from Lake Palcacocha in 1941 - when the lake volume was about $12 \times 10^{6} \mathrm{~m}^{3}$ (INDC, 2011). The 1941 GLOF caused extensive flooding in the downstream city of Huaraz, killing more than 5000 people (according to best estimates) and destroying infrastructure and agricultural land all the way to the coast (Carey, 2010; Evans et al., 2009). The recent increase in lake volume raises concerns of a persistent risk of flood for the downstream city of Huaraz. Three conditions (sustained lake growth, recent disaster antecedents, and unstable damming conditions) reinforce concerns about Lake Palcacocha as a threat for the Huaraz population and, furthermore, demand practical and applicable ways to predict potential moraine failures and water discharges from the lake.

Lake Palcacocha is dammed by a moraine composed of rock and debris deposits left behind by the retreat of the contributing glaciers. There are few geological or geotechnical studies of the current composition of the moraine, but the breach opened by the 1941 GLOF event suggests that a large portion of the moraine is composed of loose, noncohesive, and unconsolidated material (Novotny and Klimes, 2014). The front surface of the moraine at Lake Palcacocha currently exhibits what was the bottom of the 1941 breach. The differences between soil matrices at the rear and front zones of that breach channel, as well as at the crest of the moraine prior to 1941, reveal the heterogeneous and stratified structures comprising Palcacocha's moraine. Lowerelevation soil samples (shallow samples at depths of $0.1 \mathrm{~m}$ below the breach surface) are generally coarser (well-graded gravel, silty gravel, or clayey gravel) than those of higher layers of the same moraine, where clayey sand or silty sand soils predominate (Novotny and Klimes, 2014).

Since 1941, Lake Palcacocha has evolved in such a way that a new setting of the lake and moraine emerged behind the remains of the old moraine. During the catastrophic 1941 flood, the breach downcutting stopped as the lake was getting empty and the water level approached the lake bottom. 

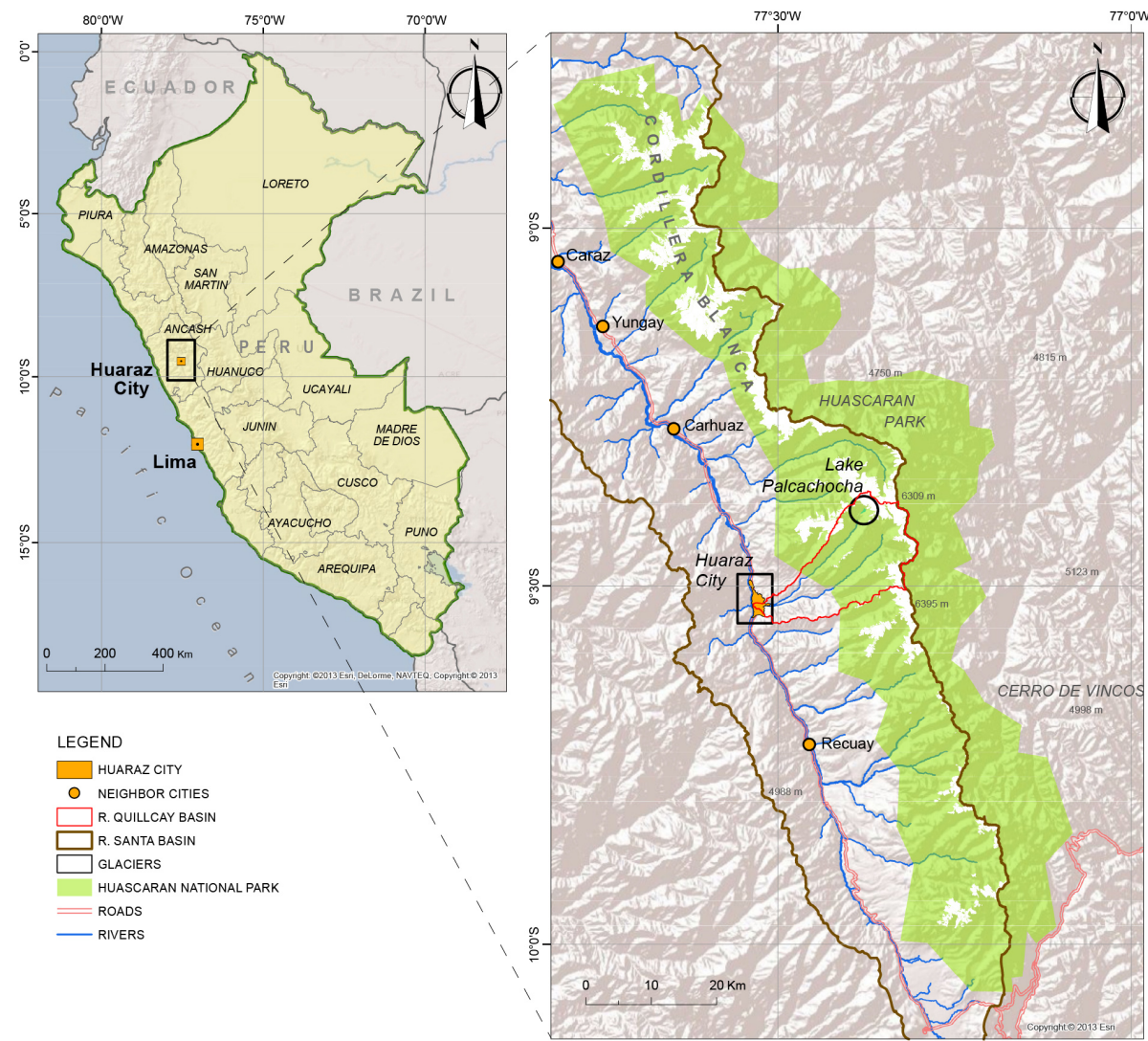

Figure 1. Lake Palcacocha location, upstream from Huaraz city in the Cordillera Blanca in Peru.

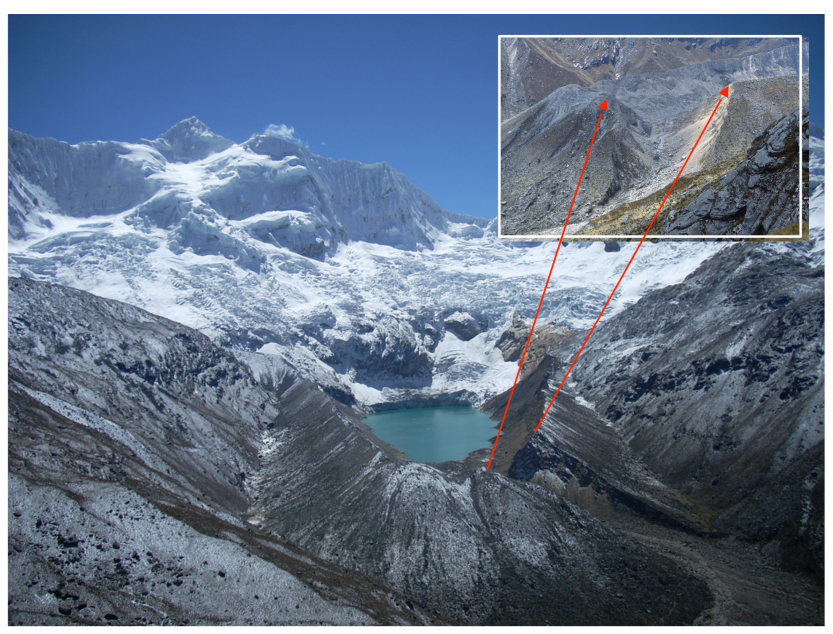

Figure 2. Front views of Lake Palcacocha and the breach of the 1941 GLOF.

That lake bottom and, indeed, the whole coupled system of moraine and lake was different to what exists now. Figure 3 reveals a profile running along Lake Palcacocha and its current moraine (derived from a $5 \mathrm{~m}$ digital elevation model (DEM) by the Ministry of Environment of Peru) (Horizons,
2013), and a reconstruction of the moraine profile before 1941 (projected from non-breached adjacent portions of the end moraine). Palcaraju Glacier has continued retreating, allowing the lake to deepen and grow upglacier, such that the bottom of the breach left by the 1941 GLOF is now the front of the current moraine (Fig. 3). Satellite images from the Advanced Spaceborne Thermal Emission and Reflection Radiometer (ASTER) mission (Fig. 4) illustrate the acceleration of those retreat-induced changes over the last decade, showing the predominant retreat direction of Palcaraju Glacier and the growth trend of Lake Palcacocha. For instance, by 2012 the lake had approximately doubled the length it exhibited in 2000 , moving its deepest point to the northeast. The deepest point of the lake in the 2009 survey $(\approx 70 \mathrm{~m})$ was not even within the domain of Lake Palcacocha in 1941. As a result, the dimensions and shape of both the lake and moraine have changed; as the volume of Lake Palcacocha has increased $\left(14 \times 10^{6} \mathrm{~m}^{3}\right.$ in 1941 to $17.2 \times 10^{6} \mathrm{~m}^{3}$ in 2009$)$, the DWH of the moraine has also increased from 6.3 to 14.9. 


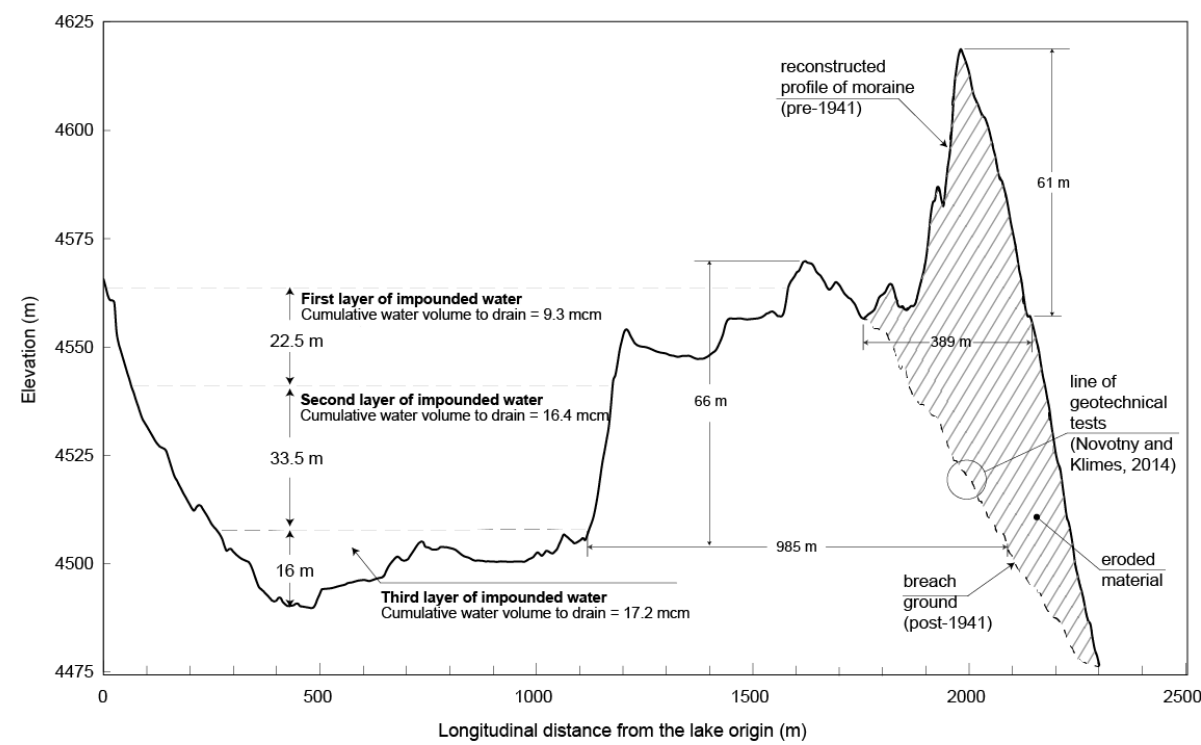

Figure 3. Palcacocha Lake and moraine longitudinal profile revealing differences between the post-1941 current moraine and a reconstruction of the moraine profile before 1941 (projected from non-breached adjacent portions of the end moraine).
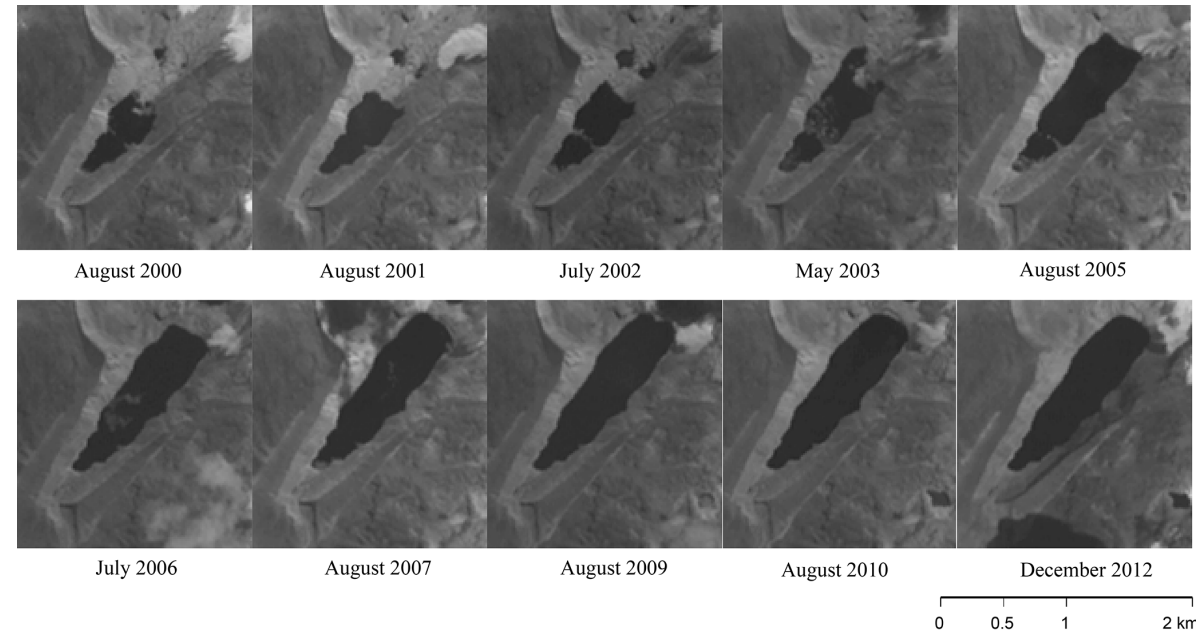

Figure 4. Growth pattern of Lake Palcacocha from 2000 to 2012: a sequence of ASTER satellite images reveal that the lake growth is following the glacier-retreat direction, changing the morphology of the lake's bottom (ASTER data from NASA Land Processes Distributed Active Archive Center).

\section{Methodology}

\subsection{Overview}

In a moraine dam failure, the outflow hydrograph depends on the stored water volume as well as the breach geometry and growth rate. For an erosive failure, the expanding rate and shape of the breach (relative to the water level) are the principal hydrographic controls. We combine empirical models and hydraulic simulations to overcome some of the limitations imposed by both the lack of knowledge of the breach formation processes and the moraine characteristics.
Under the proposed approach, selecting a proper empirical model does not rely on comparing individual characteristics of the lake or the moraine at the site. Instead, we propose that the behavior of a dam-breach process depends on several factors, including hydraulic (lake) and geomorphology or geotechnical characteristics (moraine). Therefore, an integrated assessment of the breach process should not focus on isolated characteristics of the problem, but on evaluating the model output (outflow in this case). That evaluation consists of determining whether outflow results are reasonably realistic for the site conditions: is the predicted outflow conveyable 


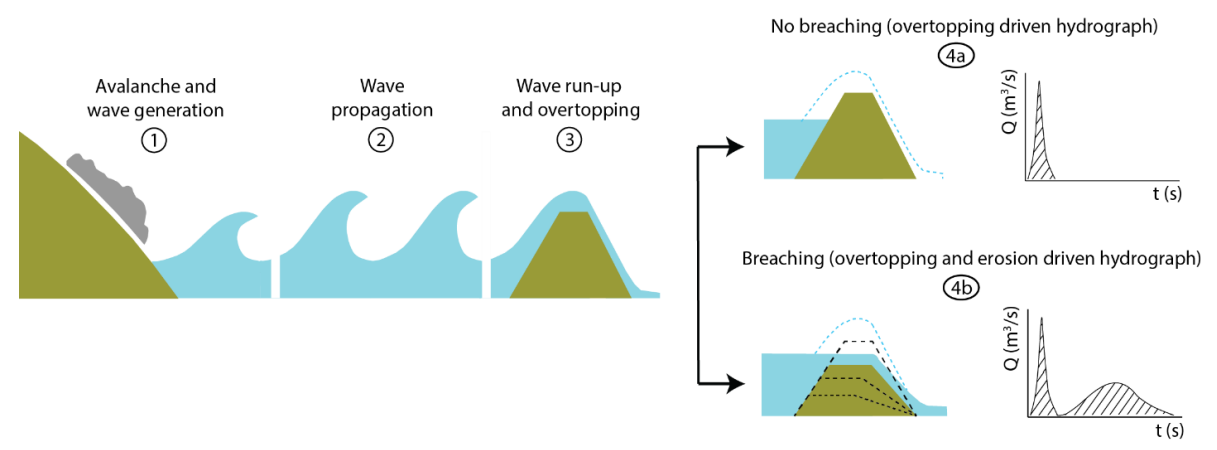

Figure 5. Sketch of a typical GLOF process chain. (1) An avalanche/landslide enters a lake, powering a wave that (2) propagates across the lake and (3) overtops the front dam moraine. As a consequence, either (4a) the waves discharge only their own water volume downstream or (4b) an erosion process starts over the moraine, such that the resulting GLOF drains waves and remaining lake volume throughout two phases, forming an overtopping- and erosion-driven hydrograph (adapted from Worni et al., 2014).

through the breach given the lake volume, available potential energy, breach dimensions, and failure time?

The approach involves four steps: (1) definition of a potential moraine breach representing a worst breach scenario, (2) peak flow and failure time estimation using empirical models, (3) calibration of a hydraulic simulation model of the moraine-breaching process using site-specific geometrical data and empirical model results, and (4) model selection and uncertainty band assessment to define an expected hydrograph of the breach outflow and its lower and upper bounds.

\subsection{Worst breach scenario: a link in a chain of GLOF processes}

A GLOF is a product of a chain of successively dependent processes (Fig. 5). The trigger mechanism initiating the whole chain might differ, taking the form of an avalanche, landslide, extreme precipitation, or earthquakes (Worni et al., 2014; Clague and Evans, 2000). As the final part of this chain, moraine dam breaching requires not only that all the preceding processes occur, but that they also set conditions to make further dam erosion possible.

The system or chain in Fig. 5 is more or less susceptible to producing a GLOF depending on a series of factors: (i) high slopes or hanging ice masses on glacier tongues, crevassed glacier snout above the lake, and proximity between glaciers and lakes may favor avalanches developing and hitting lakes surfaces (Emmer and Vilímek, 2013; O'Connor et al., 2001; Clague and Evans, 2000); (ii) singleor multiple-wave propagation response to avalanche and lake interaction, accounting for aspects like lake depth and morphology, avalanche thickness, mass, and impact angle (Worni et al., 2014); (iii) wave overtopping can occur as a consequence of wave run-up heights, lake level, and freeboard-todam-height ratios (Mergili et al., 2011; Wang et al., 2008); and (iv) breaching seems to depend on dam material properties, on piping potential, on presence of ice core or bedrock within dams, or on whether shear stresses from continuous overtopping flow exceed the material properties of moraines, producing erosion (Westoby et al., 2014).

This paper deals with only one of the processes of a potential GLOF chain at Lake Palcacocha: moraine breaching and lake emptying as a consequence of erosion. Therefore, we are envisioning a scenario where avalanches hitting the lake - and subsequent wave propagation, run-up, and overtopping - have already occurred, creating conditions to allow moraine breaching and continuous outflow from the lake.

As well as moraine material strength, freeboard (and all the sediment material behind it) plays a key role in allowing continuous outflow conditions to exist. If, after overtopping waves leave a moraine, the lake water level is not above the moraine crest, further drainage and hence erosion is not possible. Lake water level may exceed moraine elevation because (i) an event within the chain of GLOF processes destroys or cracks freeboard-providing structures, (ii) a falling mass contributes to raising the volume and lake surface level, or (iii) a combination of both phenomena. For instance, in 2002 a rock avalanche produced a GLOF at Lake Safuna Alta (Cordillera Blanca), propagating a series of waves over $100 \mathrm{~m}$ in height, allowing them to overtop the impounding moraine; however, these waves were unable to initiate any massive erosion of the dam (Hubbard et al., 2005). At that time the freeboard at Lake Safuna Alta was about $80 \mathrm{~m}$; although initial and seiche waves eroded the proximal and distal faces of the moraine, the resulting damage was insufficient to cause the lake level to exceed the moraine crest elevation after the wave overtopping (Hubbard et al., 2005).

Unlike Lake Safuna Alta, before 1941 Lake Palcacocha had no natural or artificial dams providing any stable freeboard. At that time the GLOF that killed over 5000 people downstream in Huaraz completed two stages of the GLOF chain: wave overtopping and moraine breaching (stage $4 \mathrm{~b}$ in Fig. 5), practically emptying the lake. In 1970, a combination of natural and artificial dams, and drainage structures were built at Lake Palcacocha. These $8 \mathrm{~m}$ tall and $40 \mathrm{~m}$ wide struc- 
tures, along with a drainage channel, were planned to provide stable freeboard to the lake, preventing water level from exceeding the moraine crest elevation ( $4570 \mathrm{~m}$ a.s.l.) under the influence of extreme precipitation or glacier melting discharges (INDC, 2011). However, low height and width of these partially natural dams seems susceptible to large overtopping waves because of direct-impact destruction, instant mass discharge into the lake, or progressive erosion. For instance, spatial analysis over a $5 \mathrm{~m}$ DEM (Horizons, 2013) reveals that by receiving large icefalls Lake Palcacocha can instantly increase its volume, exceeding the additional impounding capacity provided by the current freeboard (a potential volume of $3.4 \times 10^{6} \mathrm{~m}^{3}$ is contained between dam crest and regulated lake level).

In lieu of precise geotechnical and erodibility characteristics of the Lake Palcacocha moraine, which were lacking, two main criteria were used to define the potential shape and depth of the breach. First, we assume that the easiest path for water to flow through will be the path defined by the 1941 GLOF. That breach still exists, and it seems likely that a new breach would begin by eroding the old one. Second, in the case of Lake Palcacocha the worst breach depth is the full depth of the moraine. Absence of bedrock and the prevailing presence of poor cohesion materials are likely in the lake's moraine; such conditions might lead to formation of large-scale breaches. This breach scale, requiring erosion and movement of large moraine masses, is not uncommon in the history of GLOFs. In 1997 an ice avalanche over Queen Bess Lake (Canada) produced overtopping waves that started a breaching process of the moraine dam. The resulting breach reached lengths over $600 \mathrm{~m}$ and depths between 15 and $25 \mathrm{~m}$, releasing $8 \times 10^{6} \mathrm{~m}^{3}$ of impounded water; Nostetuko Lake (Canada) suffered the same kind of two-phase GLOF in 1983, which created a massive breach failure ( $480 \mathrm{~m}$ length and $40 \mathrm{~m}$ depth) (Clague and Evans, 2000). In South America, Lake Cerro Largo (Patagonian Andes) attracts attention because a GLOF in 1989 drained $24.73 \times 10^{6} \mathrm{~m}^{3}$ out of the lake, carving a $500 \mathrm{~m}$ length breach; a more recent GLOF in the Patagonian Andes region discharged $10 \times 10^{6} \mathrm{~m}^{3}\left(4100 \mathrm{~m}^{3} \mathrm{~s}^{-1}\right)$ from Lake Ventisquero Negro in 2009, eroding a $350 \mathrm{~m}$ length breach with depths up to $50 \mathrm{~m}$ (Clague and Evans, 2000; Worni et al., 2012). In 1998 a GLOF eroded the moraine dam of Tam Pokhari Lake (Mt. Everest region of Nepal), releasing a water volume of $18 \times 10^{6} \mathrm{~m}^{3}$; the resulting breach length exceeded $500 \mathrm{~m}$, with an average width and height of 60 and $50 \mathrm{~m}$, respectively (Osti and Egashira, 2009). The 1941 Palcacocha GLOF itself formed a breach through its moraine dam with a total length over $500 \mathrm{~m}$ (Fig. 3). Queen Bess Lake and Lake Cerro Largo, despite their large magnitude breaches, represent rare cases of partial moraine failure, where a relevant factor preventing deepest breaches and total collapse was the presence of bedrock within the moraine dams, making further downcutting practically impossible (Clague and Evans, 2000).
The inner structure of the soil matrix beyond the 1941 breach bottom of Lake Palcacocha's moraine is unknown. Novotny and Klimes (2014) estimate that Lake Palcacocha's moraine bedrock might include granitic/sedimentary structures, though the depth at which those bedrock structures lie is not measured. If sampled soil stratification is constant through the moraine, no bedrock should exist above the lake bottom, reinforcing the no-bedrock hypothesis and worst breach scenario adopted in this study.

The profile of the Lake Palcacocha moraine (Fig. 3) exhibits three elevation layers associated with different moraine dimensions and impounded water volumes. These specific elevation layers represent major morphologic changes in the moraine profile. As the depth of moraine increases, moraine slope decreases, allowing higher DWH ratios to lie at deeper layers. Under this morphologic setting, shallower layers are more susceptible to failure than deeper layers. The surface of the upper layer (0 to $22.5 \mathrm{~m}$ depth) seems more susceptible to erosion because it is immediately exposed to water flow and the length of a potential breach $(699 \mathrm{~m})$ at that level is about $285 \mathrm{~m}$ shorter than that of the full depth of the moraine, making the material to remove significantly lower. In terms of compaction and cohesion, these shallowest moraine layers are not necessarily less consolidated; before glacier retreat started, the moraine forming the lake dam was basal moraine of the glacier and might have been compacted by the total supported weight, at least at the proximal face of the moraine. To reach the bottom of the second layer, a breach must go as deep as $56 \mathrm{~m}$, longitudinally erode over $900 \mathrm{~m}$ of moraine material, and be able to drain $16.9 \times 10^{6} \mathrm{~m}^{3}$ of water. The likelihood of such an event is unclear, but uncertainty of the internal moraine structure does not allow us to reject the possibility of a massive breach.

Regardless the apparent morphological stability provided by its DWH ratios, the Palcacocha moraine virtually drained all of the impounded lake water behind it in 1941 (leaving something like $0.5 \times 10^{6} \mathrm{~m}^{3}$ ), creating a breach that is still in place (Fig. 2). The massive failure of this moraine in 1941 might indicate that the moraine morphology - apparently stable - is not driving its likelihood to fail. In contrast, hydraulic, freeboard, and geotechnical parameters do seem to dominate the stability conditions of the whole moraine. High DWH ratios are recurrent in moraine dams in the Cordillera Blanca. Qualitative, semi-quantitative, and quantitative assessments on potential for outbursts in this area estimate that, despite their high DWH ratios, lakes Quitacocha, Checquiacocha, Palcacocha, and Llaca are susceptible to outbursts (Emmer and Vilímek, 2013) because of susceptibility factors like proximity between lake and glacier tongue, icefall or landslide likelihood, or short moraine freeboards. These assessments consistently identify Lake Palcacocha as one of the glacial lake settings most prone to GLOFs in the region, as long as a trigger event (e.g., an avalanche in the form of an icefall, rockfall, or rock avalanche) creates an overtopping wave, favoring continuous further erosion of the front end of 


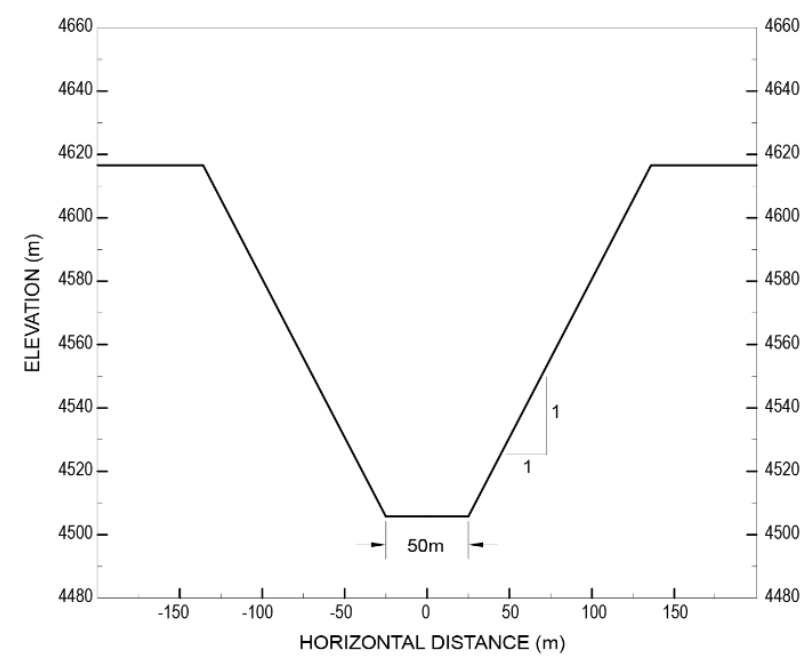

a)



b)

Figure 6. Maximum potential breach definition: (a) breach shape; (b) overlapping between the potential breach and existing terrain cross sections across the last $200 \mathrm{~m}$ of eroded moraine.

the moraine. Without this overtopping wave, current drainage structures prevent the water level from exceeding the current $8 \mathrm{~m}$ freeboard, preventing any flow over the moraine dam. Although this study only addresses the second phase of a two-phase process of overtopping wave and moraine failure, it recognizes the dependency between both phenomena and does not suggest that, in terms of hazard, one phenomenon dominates over the other.

We consider the breach depth represented by the second layer in Fig. $3(56 \mathrm{~m})$ to be the worst scenario of breaching. The third layer is constituted by a small volume $\left(0.8 \times 10^{6} \mathrm{~m}^{3}\right)$, which accounts for the remaining $5 \%$ of the entire water volume. To release that volume, water flow must erode over $1600 \mathrm{~m}$ of moraine material, extending the breach $615 \mathrm{~m}$ longer than the length developed in the second layer.



Figure 7. Volume-elevation-depth curves for Lake Palcacocha.

Thus, the water volume held in the bottom layer is unlikely to be drained with any rapidity because of the long breach length required at that depth, and low available potential energy ( $2.6 \%$ of the total potential energy of the lake) indicates the erosion time would be relatively long.

The post-1941 morphology of Lake Palcacocha moraine (Fig. 3) indicates that the outflow drained through the breach in 1941 progressively enlarged the downstream channel until the breach reached its maximum depth. By considering moraine erosion as a backward process (moving from the downstream face to the upstream face of the moraine), the shape of a maximum potential breach (Fig. 6a) should reach its maximum dimensions at the breached-channel segments close to the front toe of the moraine prior to extending backward along the whole channel. A new GLOF event could reshape the current channel left by the 1941 breach; thus the initial dimensions of a new breach would adopt the dimensions of the current breach. Based on DEM analysis (Horizons, 2013), the 1941 breach had a bottom width of $50 \mathrm{~m}$, slopes of $1: 1$ vertical to horizontal, and a depth of $56 \mathrm{~m}$ at the front toe of the moraine. This shape propagated backwards, forming the breach channel. Under this setting, a new GLOF might potentially create a new breach, starting as a deeper extension of the 1941 GLOF channel (overlaid cross sections represented by dashed lines in Fig. 6b).

Lake Palcacocha bathymetry measurements made in 2009 (UGRH, 2010) allow us to determine a volume-elevation curve for the lake (Fig. 7). The curve represents the impounded water volume as water depth increases. The parameters resulting from combining the estimated maximum potential breach shape, lake geometry, and surrounding digital terrain model are shown in Table 3. These are the inputs required by the empirical models to estimate peak outflow and failure time for the moraine breach process. The impounded water volume in Table 3 accounts for the volume of water that can be drained through the two breaches mentioned in the table, thus neglecting the water in the upper $8 \mathrm{~m}$ below 
the crest of the moraine because existing drainage structures prevent the lake from exceeding that level.

\subsection{Peak flow and failure time estimation}

The literature provides empirical models derived for different dam failure events across the world. These models are useful to define the characteristics of potential breach outflow when accurate data about dam/moraine physical conditions are not available. Nine empirical models applicable to engineered and natural dam failures are provided in Table 1. Each model provides an estimate of failure time and peak flow with the principal input data of water depth (from the initial lake free surface to the final breach) and impounded volume above the final breach. The more complex models require estimates of "erodibility" of the dam, classified as low, medium, or high. Several models also require an estimate of the breach volume as an input. These depth and volume data can be derived from digital bathymetry and terrain models once a potential breach shape is defined.

Breach dimensions, however, are important sources of uncertainty. Practical criteria to define potential breach shapes include considering that the dam might completely collapse. Even though the breach shape can vary in terms of nature, magnitude, and continuity of the trigger mechanism (avalanche-generated wave overtopping, overstorage, extreme rainfall events, etc.), estimations of GLOF peak discharges assume complete emptying of the impounded lakes (Clague and Evans, 2000; Costa and Schuster, 1988). This assumption relies on conservative approaches, which for worst breach scenarios are appropriate to support planning and mitigation actions (Laenen et al., 1987). Consequently, analysis of partial failure of moraine dams, wherever bedrock is absent, is uncommon in the literature and not accounted for in regression models.

\subsection{Dam-breach hydraulic simulation}

Dam-breach numerical simulations can be created using the US National Weather Service (NWS) DAMBRK dam-breach method (Fread, 1984). Extensive descriptions of the mathematical basis of DAMBRK can be found in Fread (1984, 1988, 1994). DAMBRK simulates the breach outflow process as an idealized hydraulic process: i.e., one-dimensional open-channel flow over a broad-crested weir that linearly evolves with time (Wahl, 2004; Wurbs, 1987; DHI, 2008). This approach excludes erosion physics and hence does not require geotechnical or structural parameters. A major disadvantage is the assumption of regular breach shapes and linear growth (Wurbs, 1987), which oversimplifies breach development in heterogeneous materials such as moraines. The DAMBRK breach development is not based on erosive processes, and the user must define it as part of the input data. The definition includes both the maximum breach dimensions and the time to failure (i.e., to maximum breach).
In a DAMBRK simulation, the breach starts at the crest of the dam/moraine and grows in both vertical and horizontal directions, deepening and widening the breach shape. This assumption does not reflect real-world processes of moraine dam breaches. Field observations suggest that backward erosion, from the front end of the dam to the dam crest, is an important process in dam-breach formation. The DAMBRK model, under the assumption of top-to-bottom breach development, intends to produce results equivalent to real dam-breach situations, not to thoroughly reproduce the process. The coupled modeling approach (empirical model/dambreach model) might provide the constraining parameters (peak flow, time of failure, volume under the hydrograph) to reach those equivalent results.

During each time step of a DAMBRK simulation, the discharge and energy head vary according to water level, available volume, and breach (weir) dimensions. The parameters used in the moraine breach model are impounded lake geometry, surrounding terrain topography, breach shape, and failure times; the basic physical parameters are the same as those applied to the empirical models described in the previous section, including the elevation-volume curve, but are used in greater site-specific detail within DAMBRK rather than integrated to simple height and volume values as used in empirical models.

\subsection{Assessment of empirical equation performance}

For most potentially dangerous glacial lakes, there are few (if any) data to calibrate hydraulic simulations, and essentially no independent data sets for validation. Note that the portion of the moraine at Lake Palcacocha that today could erode is well behind the 1941 GLOF erosion area (Fig. 3), such that simulating the 1941 event for calibration purposes may not be meaningful if our concern is present-day hazard reduction. Also, quantitative information about the 1941 event is not available that could be used to validate a presentday model. We refer to data for validation as independent hydraulic data such as peak outflow, failure time, streamflow measurements, flood depths, or precise flooded areas. In the Cordillera Blanca, however, there is available only geomorphologic evidence of breach dimensions of historical GLOF events-breach dimensions remain over time, unless a new GLOF or severe geomorphic event reshapes them (Hubbard et al., 2005; Novotny and Klimes, 2014).

Herein, we propose using the empirical models to provide estimates of the peak flow rate and failure time for calibration of DAMBRK. The failure time from a given empirical model is used as input data in DAMBRK as a first estimate of the failure time. The DAMBRK simulation is run and the peak flow of the resulting hydrograph is compared to the peak flow of the empirical model. The DAMBRK input failure time is then adjusted in successive runs until the peak flows of the simulation and empirical models are approximately matched. The difference between the failure time from the final simu- 
Table 1. Empirical equations for peak flow and failure time for dam-breach events.

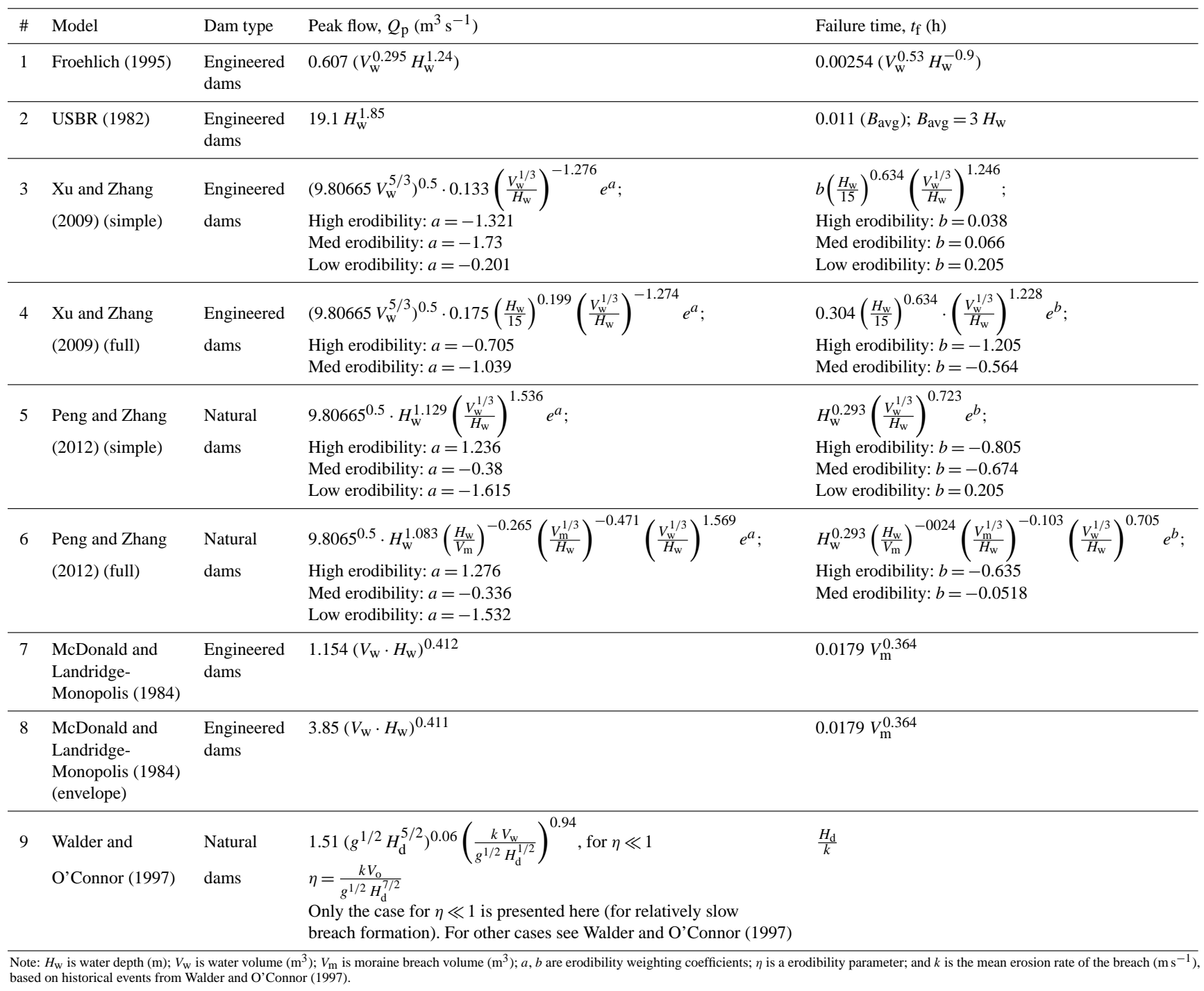

lation and the empirical model is used to assess the quality of the different empirical models and select the hydrographs that can be considered the most robust estimate of a potential dam breach.

Using the DAMBRK model, the proposed approach does not seek to thoroughly simulate hydro-erosive processes, but to determine whether empirical model estimations are hydraulically feasible for the study site. Coupled lake-breach settings cannot produce peak outflows out of the range of the hydraulic capacity of the breach or the available energy and volume of the lake. Under this approach, contrasting DAMBRK models and empirical models serves to reasonably measure the capability of empirical models to reproduce those coupled lake-breach settings. If the results of a given empirical model indicate that peak outflow estimations exceed the hydraulic capacity of the breach, such results are unrealistic or unfeasible. The capability of DAMBRK to sim- ulate a breach conveyance capacity serves to screen and assess the empirical models performance and how suitable they are to represent the coupled lake-breach settings at the Palcacocha site. This assessment leads to hydrographs that can be considered robust and hydraulically consistent estimates of a potential dam breach.

For these comparisons, it is useful to define a normalized flow difference $\left(Q_{\mathrm{d}}\right)$ from the peak flow of the empirical model $\left(Q_{\mathrm{pE}}\right)$ and the peak flow of the hydraulic simulation $\left(Q_{\mathrm{pH}}\right)$ as

$Q_{\mathrm{d}}=\frac{\left|Q_{\mathrm{pE}}-Q_{\mathrm{pH}}\right|}{Q_{\mathrm{pE}}} \times 100 \%$,

where the calibration is considered adequate when $Q_{\mathrm{d}}<2 \%$. The empirical model performance is governed by a similar normalized time difference of 
Table 2. Uncertainty estimates for peak flow predictions using empirical models (adapted from Wahl, 2004; Xu and Zhang, 2009; and Peng and Zhang, 2012).

\begin{tabular}{lcccc}
\hline Author & $\begin{array}{c}\text { Number } \\
\text { of case } \\
\text { studies }\end{array}$ & $\begin{array}{c}\text { Mean } \\
\text { prediction } \\
\text { error, } \bar{e} \\
\text { (log } \\
\text { cycles) }\end{array}$ & $\begin{array}{c}\text { Width of } \\
\text { uncertainty } \\
\text { band, } \pm 2 \text { Se } \\
\text { (log } \\
\text { cycles) }\end{array}$ & $\begin{array}{c}\text { Prediction } \\
\text { interval around } \\
\text { hypothetical } \\
\text { predicted value } \\
\text { of 1 }\end{array}$ \\
\hline Froehlich (1995) & 32 & -0.04 & \pm 0.32 & $0.53-2.3$ \\
\hline USBR (1982) & 38 & +0.19 & \pm 0.50 & $0.2-2.1$ \\
\hline $\begin{array}{l}\text { Xu and Zhang (2009) } \\
\text { (simple) }\end{array}$ & 14 & - & \pm 0.48 & $0.33-3.01$ \\
\hline $\begin{array}{l}\text { Xu and Zhang (2009) } \\
\text { (full) }\end{array}$ & 14 & - & \pm 0.52 & $0.30-3.35$ \\
\hline $\begin{array}{l}\text { Peng and Zhang (2012) } \\
\text { (simple) }\end{array}$ & 41 & - & \pm 0.48 & $0.33-3.03$ \\
\hline $\begin{array}{l}\text { Peng and Zhang (2012) } \\
\text { (full) }\end{array}$ & 41 & - & \pm 0.47 & $0.34-2.9$ \\
\hline $\begin{array}{l}\text { McDonald and Landridge- } \\
\text { Monopolis (1984) }\end{array}$ & 37 & +0.13 & \pm 0.70 & $0.15-3.7$ \\
\hline $\begin{array}{l}\text { McDonald and Landridge- } \\
\text { Monopolis (1984) (envelope) }\end{array}$ & 37 & +0.64 & \pm 0.70 & $0.05-1.10$ \\
\hline \begin{tabular}{l} 
Walder and O'Connor (1997) \\
\hline
\end{tabular} & 22 & +0.13 & \pm 0.68 & $0.16-3.60$ \\
\hline
\end{tabular}

Table 3. Physical parameters for moraine breach models of Lake Palcacocha.

\begin{tabular}{ll}
\hline Parameter & Maximum breach \\
\hline Depth of water $\left(H_{\mathrm{W}}\right)$ & $49.7 \mathrm{~m}$ \\
Depth of the breach $\left(H_{\mathrm{d}}\right)$ & $56.0 \mathrm{~m}$ \\
Volume of impounded water not including the lower zone $\left(V_{\mathrm{w}}\right)$ & $16.9 \times 10^{6} \mathrm{~m}^{3}$ \\
Volume of moraine breach $\left(V_{\mathrm{m}}\right)$ & $3.65 \times 10^{6} \mathrm{~m}^{3}$ \\
Bottom width $(\mathrm{m})$ & $50.0 \mathrm{~m}$ \\
Breach slopes & $1: 1$ horizontal to vertical \\
\hline
\end{tabular}

$t_{\mathrm{d}}=\frac{\left|t_{\mathrm{fE}}-t_{\mathrm{fH}}\right|}{t_{\mathrm{fE}}} \times 100 \%$

where $t_{\mathrm{fE}}$ and $t_{\mathrm{fH}}$ are the failure times for the empirical and the hydraulic simulation models, respectively. As $Q_{\mathrm{d}}$ is used for judging calibration, the resulting $t_{\mathrm{d}}$ is used to assess model performance.

\subsection{Model selection and probabilistic assessment}

Each empirical equation has an uncertainty band resulting from the residuals of the underlying regression model. The uncertainty bandwidth of the breaching parameters (i.e., the range between lower and upper bounds of predictions) reflects the likely variability for each model's predictions of peak flow. Wahl (2004), Xu and Zhang (2009), and Peng and
Zhang (2012) developed analysis methods for uncertainty bands. The empirical models of Table 1 have the mean prediction error $(\bar{e})$ and standard deviation of the error $(\mathrm{Se})$ as shown in Table 2 . The $\bar{e}$ are the number of log cycles separating predicted and observed peak flows in the individual case studies compiled by each author. The sign of $\bar{e}$ indicates overor underestimation of peak outflows (Wahl, 2004). With the exception of the Froehlich model (Froehlich, 1995), all empirical models tend to overestimate peak outflows. This trend is consistent with prevailing conservative approaches of dambreak prediction and the adoption of worst-case scenarios in flood risk studies (Laenen et al., 1987). We apply a prediction interval as the expected lower $\left(Q_{1}\right)$ and upper $\left(Q_{\mathrm{u}}\right)$ bounds on the peak outflow as plus or minus 2 standard deviations from the mean error, i.e., 


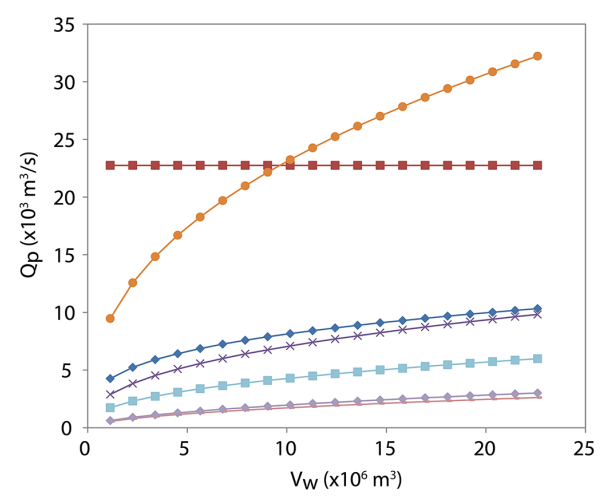

(a)

$$
\begin{array}{ll}
\rightarrow-\text { Froehlich } & \rightarrow \text { Xu and Zhang (full - med. erod.) } \\
\rightarrow-\text { USBR } & - \text { Peng and Zhang (simple - med. erod.) } \\
* \text { Xu and Zhang (simple - med. erod.) } & \rightarrow \text { Peng and Zhang (full - med. erod.) }
\end{array}
$$

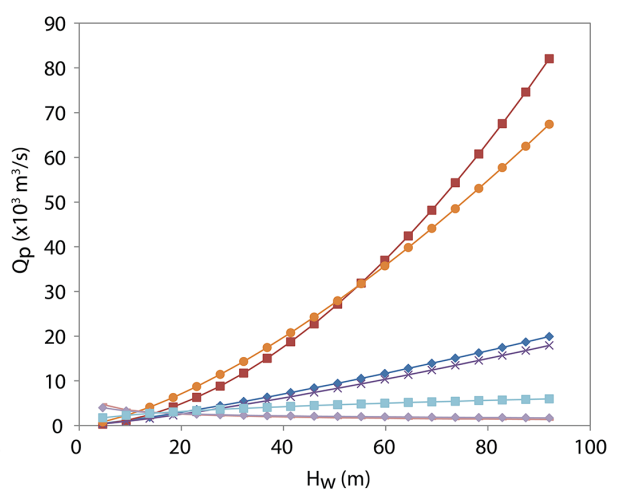

(b)

Figure 8. Peak flow response to (a) water volume variations, and (b) water depth variations according to selected empirical models.

$$
Q_{1}, Q_{\mathrm{u}}=\left\{Q_{\mathrm{p}} \times 10^{-\bar{e}-2 \mathrm{Se}}, Q_{\mathrm{p}} \times 10^{-\bar{e}+2 \mathrm{Se}}\right\},
$$

where $Q_{\mathrm{p}}$ is the predicted outflow. Comparison of the prediction interval for the empirical models is provided in Table 2. The prediction interval is an inherent characteristic of each empirical model, or, to be more precise, it is a characteristic of each model when compared with actual values of the original sample of dam breaks used in the regression.

We can use the prediction interval values to estimate the range of hydrographs expected for a hydraulic simulation calibrated with a particular empirical model. That is, we can adjust the failure time of the hydraulic simulation in successive runs to match the $Q_{1}$ and $Q_{\mathrm{u}}$, obtaining hydrographs that are the expected range of a potential dam break.

\section{Results and discussion}

\subsection{Comparison of empirical models}

Each empirical model assigns different coefficients and functional forms to the input data (see Table 1), which provide different relationships for flow depth and flow volume. Figure 8 presents variations in the peak flow $\left(Q_{\mathrm{p}}\right)$ estimated by a subset of empirical models as a function of water volume, $V_{\mathrm{W}}$ (Fig. 8a) and water depth, $H_{\mathrm{w}}$ (Fig. 8b). The slopes in Fig. 8 reflect the weights each model assigns to $V_{\mathrm{w}}$ and $H_{\mathrm{w}}$ as predictors of $Q_{\mathrm{p}}$. As indicated in Fig. 8a, a simple model such as USBR (1982) is insensitive to changes in $V_{\mathrm{w}}$ since the model does not include that parameter. Although there are scale differences, models such as Froehlich (1995), Xu and Zhang "simple" (Xu and Zhang, 2009), and Peng and Zhang "simple" and "full" (Peng and Zhang, 2012) show similar responses to $V_{\mathrm{w}}$ variations. However, Xu and Zhang "full" (Xu and Zhang, 2009), the only model that accounts for volume of eroded material, is more sensitive to variations in $V_{\mathrm{w}}$. Fig- ure $8 \mathrm{a}$ also suggests that, in general, empirical equations are more sensitive to changes in $V_{\mathrm{w}}$ at lower volumes.

Figure $8 \mathrm{~b}$ shows three trends in the behavior of $Q_{\mathrm{p}}$ as $H_{\mathrm{w}}$ increases. First, the $\mathrm{Xu}$ and Zhang full (Xu and Zhang, 2009) and USBR (1982) models weight $H_{\mathrm{w}}$ more heavily as a predictor of $Q_{\mathrm{p}}$, but there is a transition point $\left(H_{\mathrm{w}}=55 \mathrm{~m}\right)$ where the effect of $H_{\mathrm{w}}$ changes are more evident (higher slope) in the USBR (1982) model, leading to higher differences between the predictions of these models. Second, the Froehlich (1995) and Xu and Zhang simple (Xu and Zhang, 2009) models present moderate and more constant slopes, indicating that the influence of $H_{\mathrm{w}}$ is less pronounced than in the first group. Third, the Peng and Zhang full (Peng and Zhang, 2012) and McDonald and LandridgeMonopolis (1984) models have almost horizontal slopes, indicating that they are less sensitive to changes in $H_{\mathrm{w}}$.

\subsection{Comparison of empirical and DAMBRK model results}

Table 4 summarizes the peak flow and failure time results for the empirical models listed in Table 1 and the DAMBRK models considering a Lake Palcacocha moraine breach. The range of normalized peak flow difference $\left(Q_{\mathrm{d}}\right)$ is 0.04 $1.84 \%$ with a median value of $0.47 \%$. These low values are the result of $Q_{\mathrm{d}}$ being matched during calibration. The range of the normalized failure time difference $\left(t_{\mathrm{d}}\right)$ is 19.6$96.8 \%$ with a median of $71.6 \%$. The results suggest that, in this case, the Froehlich (1995) model performs better than the other models because the $t_{\mathrm{d}}=19.6 \%$, which is the smallest for the 14 models. The simplicity of the Froehlich (1995) model reduces the prediction uncertainty that is implicitly added by erodibility conditions in other models such as $\mathrm{Xu}$ and Zhang (2009), Peng and Zhang (2012), or McDonald and Landridge-Monopolis (1984), for which the normalized differences of time failure are over $90 \%$. More complex mod- 
Table 4. Peak outflow (calibrated) and breach failure time (result) estimated by empirical models and hydraulic simulation for Lake Palcacocha.

\begin{tabular}{|c|c|c|c|c|c|c|c|c|}
\hline \multirow[t]{2}{*}{ \# } & \multirow[t]{2}{*}{ Reference } & \multirow{2}{*}{$\begin{array}{l}\text { Erodibility } \\
\text { condition }\end{array}$} & \multicolumn{2}{|c|}{ Empirical models } & \multicolumn{2}{|c|}{ Hydraulic simulation } & \multicolumn{2}{|c|}{ Normalized difference } \\
\hline & & & $\begin{array}{l}\text { Peak flow } \\
Q_{\mathrm{pE}} \\
\left(\mathrm{m}^{3} \mathrm{~s}^{-1}\right)\end{array}$ & $\begin{array}{c}\text { Failure } \\
\text { time } \\
t_{\mathrm{fE}} \\
(\mathrm{h})\end{array}$ & $\begin{array}{r}\text { Peak flow } \\
Q_{\mathrm{pH}} \\
\left(\mathrm{m}^{3} \mathrm{~s}^{-1}\right)\end{array}$ & $\begin{array}{c}\text { Failure } \\
\text { time } \\
t_{\mathrm{fH}} \\
(\mathrm{h})\end{array}$ & $\begin{array}{c}\text { Flow } \\
Q_{\mathrm{d}} \\
(\%)\end{array}$ & $\begin{array}{c}\text { Time } \\
t_{\mathrm{d}} \\
(\%)\end{array}$ \\
\hline 1 & Froehlich (1995) & & 10426 & 0.51 & 10412 & 0.61 & 0.14 & 19.62 \\
\hline 2 & $\begin{array}{l}\text { Bureau of } \\
\text { Reclamation }\end{array}$ & & 26260 & 1.64 & 26659 & 0.15 & 1.52 & 91.11 \\
\hline $3 a$ & $\begin{array}{l}\text { Xu and Zhang (2009) } \\
\text { (simple) }\end{array}$ & Med & 9567 & 1.09 & 9556 & 0.68 & 0.11 & 37.45 \\
\hline $3 b$ & $\begin{array}{l}\text { Xu and Zhang (2009) } \\
\text { (simple) }\end{array}$ & High & 14401 & 0.63 & 14306 & 0.43 & 0.66 & 31.27 \\
\hline $3 c$ & $\begin{array}{l}\text { Xu and Zhang (2009) } \\
\text { (simple) }\end{array}$ & Low & 3756 & 3.38 & 3825 & 1.85 & 1.84 & 45.34 \\
\hline $4 a$ & $\begin{array}{l}\text { Xu and Zhang (2009) } \\
\text { (full) }\end{array}$ & Med & 32953 & 3.02 & 32727 & 0.10 & 0.69 & 96.78 \\
\hline $4 \mathrm{~b}$ & $\begin{array}{l}\text { Xu and Zhang (2009) } \\
\text { (full) }\end{array}$ & High & 44674 & 1.59 & 44624 & 0.05 & 0.11 & 96.77 \\
\hline $5 a$ & $\begin{array}{l}\text { Peng and Zhang (2012) } \\
\text { (simple) }\end{array}$ & Med & 2186 & 5.24 & 2212 & 3.33 & 1.18 & 36.36 \\
\hline $5 b$ & $\begin{array}{l}\text { Peng and Zhang (2012) } \\
\text { (simple) }\end{array}$ & High & 11002 & 4.59 & 11007 & 0.58 & 0.04 & 87.30 \\
\hline $6 a$ & $\begin{array}{l}\text { Peng and Zhang (2012) } \\
\text { (full) }\end{array}$ & Med & 2533 & 9.03 & 2504 & 2.92 & 1.16 & 67.72 \\
\hline $6 b$ & $\begin{array}{l}\text { Peng and Zhang (2012) } \\
\text { (full) }\end{array}$ & High & 12699 & 5.04 & 12664 & 0.50 & 0.27 & 90.08 \\
\hline 7 & $\begin{array}{l}\text { McDonald and } \\
\text { Landridge-Monopolis } \\
(1984)\end{array}$ & & 5469 & 4.38 & 5369 & 1.28 & 1.83 & 70.83 \\
\hline 8 & $\begin{array}{l}\text { McDonald and } \\
\text { Landridge-Monopolis } \\
\text { (1984) (envelope) }\end{array}$ & & 17876 & 4.38 & 17897 & 0.32 & 0.12 & 92.71 \\
\hline 9 & $\begin{array}{l}\text { Walder and O'Connor } \\
\text { (1997) }\end{array}$ & & 20246 & 0.95 & 20271 & 0.26 & 0.12 & 72.40 \\
\hline & & & & & & $\begin{array}{c}\text { Min } \\
\text { Max } \\
\text { Median }\end{array}$ & $\begin{array}{l}0.04 \\
1.84 \\
0.47\end{array}$ & $\begin{array}{l}19.62 \\
96.78 \\
71.61\end{array}$ \\
\hline
\end{tabular}

els that incorporate erosion parameters to estimate breach formation and peak outflow might become more relevant in cases where the erosion parameters are better known. However, additional erodibility parameters seem to bring additional uncertainty in the case of Lake Palcacocha, where the geotechnical characteristics of the moraine are mostly unknown. The only available data correspond to shallow soil samples, whose composition indicates that lower-elevation soils (close to the toe of the moraine) consist of well-graded gravel, silty gravel, or clayey gravel, while finer soils predominate at higher layers of the moraine, including clayey sand or silty sand (Novotny and Klimes, 2014).

The hydraulic simulation performs a second function. Besides measuring the capability of the best-performing em- 


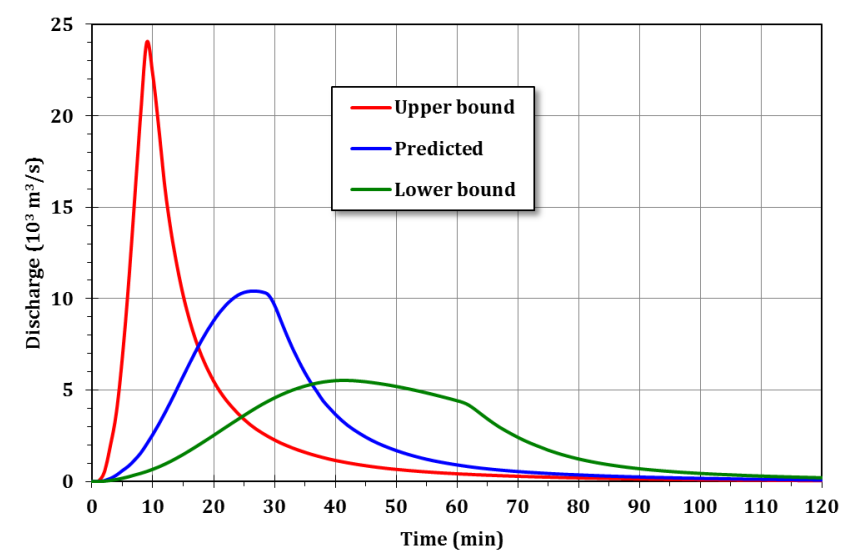

Figure 9. Potential outflow hydrographs from Lake Palcacocha due to a $56 \mathrm{~m}$ moraine breach.

pirical model to provide reasonable outflow estimations, it produces full outflow hydrographs for the expected breach and the corresponding lower and upper uncertainty bounds. Figure 9 shows the range of hydrographs generated using DAMBRK to simulate the discharge of a $56 \mathrm{~m}$ deep breach in the frontal moraine of Lake Palcacocha.

\subsection{Limitations and advantages}

The approach presented here is inherently limited. The criteria used to compare the models are relative; that is, we consider one empirical model performs better than another one if its predicted peak flow can be used to obtain a smaller difference between its predicted time to failure and the time to failure computed with the hydraulic simulation. We can find no obvious thresholds for judging what difference levels are significant in an absolute sense. Furthermore, the approach relies on the hydraulic simulation providing a reasonable representation of the outflow hydrograph. If the simplification of the hydraulic simulation is inappropriate, the resulting analysis of the empirical models is invalid.

We do not provide data for independent validation. The core idea behind the approach we propose is that we lack independent data for validation, as is the case in most remote areas where glacial lakes exist and this methodology might apply. Instead, we propose that it is possible to evaluate the suitability of empirical models by verifying that the produced results are hydraulically realistic (i.e., outflow results do not deviate from the conveyance capacity of the defined breach). This kind of assessment is a step forward in empirical model application for dam-breach failures. The approach is not an integral solution for dam-breach problems, since it is supported solely by hydraulic modeling. Geotechnical information only supports the no-bedrock hypothesis and poor cohesion description of the soil matrix from a qualitative point of view. However, the results do rely on physical properties of the problem (lake and moraine interaction to produce out-
Table 5. Mean prediction errors for failure time and peak flow, width of uncertainty bands, and prediction interval (for hypothetical value of 1) using Froehlich's equations (Wahl, 2004).

\begin{tabular}{lccc}
\hline Parameter & $\begin{array}{c}\text { Mean } \\
\text { prediction } \\
\text { error } \\
(\log \\
\text { cycles })\end{array}$ & $\begin{array}{c}\text { Width of } \\
\text { uncertainty } \\
\text { band }( \pm 2 \mathrm{Se}) \\
\text { (log cycles) }\end{array}$ & $\begin{array}{c}\text { Prediction } \\
\text { interval } \\
\text { around } \\
\text { hypothetical } \\
\text { predicted } \\
\text { value of } 1\end{array}$ \\
\hline $\begin{array}{l}\text { Failure time } \\
\text { Peak discharge }\end{array}$ & -0.22 & \pm 0.64 & $0.38-7.30$ \\
& -0.04 & \pm 0.32 & $0.53-2.30$ \\
\hline
\end{tabular}

flow), rather than only on statistical parameters or individual comparison of lake and moraine characteristics.

Finally, we note that the preferred empirical model in this study, Froehlich (1995), is only for the Lake Palcacocha and that results cannot be generalized to other lakes; however, the same approach could be applied to other lakes to select a model and produce hydrographs. Because the lake and dam geometry affect the hydraulic simulation of the dam break, it is entirely possible that a different lake/dam would produce hydrographs better matching a different empirical equation.

The main advantages of this approach reside in its simplicity and robustness, making it useful in situations where data are sparse, such as in the analysis of the risk of glacial lakes. The approach takes a step beyond the previous empirical models by providing a method to estimate a dambreak hydrograph that could be used for more effective modeling of potential downstream consequences. Another advantage emerges from further applying the results to risk assessment or vulnerability studies. Focusing more specifically on the Froehlich empirical model (Froehlich, 1995), Table 5 shows the mean prediction errors for failure time and peak discharge, the width of the uncertainty bands, and the prediction interval for a hypothetical predicted value of 1 using Froehlich's equations (Wahl, 2004). Table 6 shows the predicted peak outflow and failure time estimated by the Froehlich empirical model and hydraulic simulation and the associated prediction intervals (upper and lower bounds) for Lake Palcacocha conditions. The hydrographs in Fig. 9 present an outflow event and the lower and upper bounds for a $56 \mathrm{~m}$ breach from Lake Palcacocha. Instead of providing a single outflow result, this approach allows risk studies to take into account a range of possible events accounting for the uncertainty in the breaching calculations.

\section{Conclusions}

A new approach has been presented for extending prior empirical models that provide only peak flows and failure times for a dam break. Following this new approach, it is possible to determine the maximum and minimum flow hydrographs 
Table 6. Predicted peak outflow and failure time estimated by Froehlich's empirical models and hydraulic simulation and the associated prediction intervals (upper and lower bounds) for Lake Palcacocha conditions.

\begin{tabular}{|c|c|c|c|c|c|c|}
\hline \multirow[t]{2}{*}{ Parameter } & \multicolumn{2}{|c|}{ Empirical model } & \multicolumn{2}{|c|}{ Hydraulic simulation } & \multicolumn{2}{|c|}{$\begin{array}{c}\text { Normalized } \\
\text { differences }\end{array}$} \\
\hline & $\begin{array}{r}Q_{\mathrm{pE}} \\
\left(\mathrm{m}^{3} \mathrm{~s}^{-1}\right)\end{array}$ & $\begin{array}{l}t_{\mathrm{fE}} \\
(\mathrm{h})\end{array}$ & $\begin{array}{r}Q_{\mathrm{pH}} \\
\left(\mathrm{m}^{3} \mathrm{~s}^{-1}\right)\end{array}$ & $\begin{array}{l}t_{\mathrm{fH}} \\
(\mathrm{h})\end{array}$ & $\underset{(\%)}{Q_{\mathrm{d}}}$ & $\begin{array}{r}t_{\mathrm{d}} \\
(\%)\end{array}$ \\
\hline Lower bound & 5526 & 3.72 & 5533 & 1.24 & 0.13 & 66.69 \\
\hline Predicted value & 10426 & 0.51 & 10412 & 0.61 & 0.13 & 19.61 \\
\hline Upper bound & 23980 & 0.19 & 24016 & 0.19 & 0.15 & 1.96 \\
\hline
\end{tabular}

that are consistent with the empirical model. The resulting approach evaluates existing empirical models to find the best match to the hydrograph produced by calibrating a hydraulic simulation. In the present study, the DAMBRK model was used, but the approach could be adapted to any unsteadyflow hydraulic simulation method. The advantage of the approach is that it provides a simple way to estimate a hydrograph for potential dam breaks where data are limited, which is the case for many glacial lakes that endanger downstream populations.

Application of this approach to detailed dam-break studies, which require less uncertainty, remains limited due to lack of precise validation data. Furthermore, the inner nature of the applied empirical models, built upon specific sets of historical cases, limits the range of locations where the models are reliable, which prevents us from applying the method in a generalized way. Rather, the method requires careful judgment in evaluating model performances through normalized differences of time failures.

Implementation of this new approach was demonstrated in estimating the hydrographs for potential breaches in a moraine-dammed glacial lake (Lake Palcacocha, Peru). The best results were obtained using the Froehlich (1995) empirical model, with an error of $19.6 \%$ in failure time. Uncertainty of predicted outflows and corresponding hydrographs are computed for every empirical model studied. Using the suggested approach, we were able to predict expected outflow hydrographs and their uncertainty range (lower and upper bound hydrographs).

Acknowledgements. The authors acknowledge the support of the USAID Climate Change Resilient Development (CCRD) project and the Fulbright Foundation for the support of D. S. Rivas and M. A. Somos-Valenzuela. B. R. Hodges was partially supported by National Science Foundation under grant no. CCF-1331610. The authors also appreciate the collaboration of NASA and USGS EROS Center, providing privileges to order ASTER data from the Land Processes Distributed Active Archive Center (LP DAAC). The support of Josefa Rojas and Ricardo Ramirez Villanueva of the IMACC project of the Peruvian Ministry of Environment provided valuable assistance in obtaining the new DEM of the Quillcay watershed. The comments of Adam Emmer and two anonymous reviewers are appreciated as they greatly improved the paper.
Edited by: M. Parise

Reviewed by: two anonymous referees

\section{References}

Burns, P. and Nolin, A.: Using atmospherically-corrected Landsat imagery to measure glacier area change in the Cordillera Blanca, Peru from 1987 to 2010, Remote Sens. Environ., 140, 165-178, doi:10.1016/j.rse.2013.08.026, 2014.

Carey, M.: Living and dying with glaciers: people's historical vulnerability to avalanches and outburst floods in Peru, Global Planet. Change, 47, 122-134, doi:10.1016/j.gloplacha.2004.10.007, 2005.

Carey, M.: In the Shadow of Melting Glaciers: Climate Change and Andean Society, Oxford Univ. Press, New York, 2010.

Clague, J. J. and Evans, S. G.: A review of catastrophic drainage of moraine-dammed lakes in British Columbia, Quaternary Sci. Rev., 19, 1763-1783, 2000.

Costa, J. E. and Schuster, R. L.: The formation and failure of natural dams, Geol. Soc. Am. Bull., 100, 1054-1068, 1988.

DHI - Danish Hydraulic Institute: A modelling system for Rivers and Channels, Copenhagen, 2008.

Emmer, A. and Vilímek, V.: Review Article: Lake and breach hazard assessment for moraine-dammed lakes: an example from the Cordillera Blanca (Peru), Nat. Hazards Earth Syst. Sci., 13, 1551-1565, doi:10.5194/nhess-13-1551-2013, 2013.

Evans, S. G., Bishop, N. F., Smoll, L. F., Valderrama-Murillo, P., Delaney, K. B., and Oliver-Smith, A.: A re-examination of the mechanism and human impact of catastrophic mass flows originating on Nevado Huascarán, Cordillera Blanca, Peru in 1962 and 1970, Eng. Geol., 108, 96-118, 2009.

Fread, D. L.: DAMBRK: The NWS dam-break flood forecasting model, National Weather Service, Office of Hydrology, Silver Spring, MD, 1984.

Fread, D. L.: DAMBRK: The NWS DAMBRK Model: Theoretical Background/User Documentation, Hydrologic Research Laboratory, National Weather Service, Office of Hydrology, Silver Spring, MD, 1988.

Fread, D. L.: NWS FLDWAV Model: The Replacement of DAMBRK for Dam-Break Flood Prediction, Hydrologic Research Laboratory, National Weather Service, Office of Hydrology, Silver Spring, MD, 1994.

Froehlich, D. C.: Peak outflow from breached embankment dam, J. Water Resour. Pl. Manage., 121, 90-97, 1995. 
Froehlich, D. C.: Embankment dam breaches and their uncertainties, J. Water Resour. Pl. Manage., 121, 90-97, 2008.

Hanson, G. J., Temple, D. M., Morris, M., Hassan, M., and Cook, K.: Simplified breach analysis model for homogeneous embankments: Part II, Parameter inputs and variable scale model comparisons, Proceedings of 2005 US Society on Dams Annual Meeting and Conference, 6-10 June 2005, Salt Lake City, 1511612005.

Horizons - Horizons South America S. A. C.: Informe Técnico del Proyecto, Consultoría Para El Levantamiento Fotogramétrico Detallado De La Sub Cuenca Del Río Quillcay Y La Ciudad De Huaraz Para El Proyecto, Implementación de Medidas de Adaptación al Cambio Climático y Gestión de Riesgos en la Subcuenca Quillcay (IMACC-QUILLCAY) - BID-MINAM (PE$T$ 1168), Ministerio Del Ambiente A Travel Del Fonam - Administrador De Los Recursos Del BID, Lima, Peru, 2013.

Hubbard, B., Heald, A., Reynolds, J. M., Quincey, D., Richardson, S. D., Luyo, M. Z., Portilla, N. S., and Hambrey, M. J.: Impact of a rock avalanche on a moraine-dammed proglacial lake: Laguna Safuna Alta, Cordillera Blanca, Peru, Earth Surf. Proc. Land., 30, 1251-1264, 2005.

Huggel, C., Haeberli, W., Kääb, A., Bieri, D., and Richardson, S.: An assessment procedure for glacial hazards in the Swiss Alps, Can. Geotech. J., 41, 1068-1083, 2004.

INDC - Instituto Nacional de Defensa Civil: Informe de peligro No. 003-12/05/2011/COEN-SINADECI/15:00 horas (Informe No. 01): Peligro por aluvión en el departamento de Ancash, COEN-SINADECI, Huaraz-Peru, 2011.

Kershaw, J. A., Clague, J. J., and Evans, S. G.: Geomorphic and sedimentological signature of a two phase outburst flood from moraine-dammed Queen Bess Lake, British Columbia, Canada, Earth Surf. Proc. Land., 30, 1-25, 2005.

Laenen, A., Scott, K. M., Costa, J. E., and Orzol, L.: Hydrologic Hazards along Squaw Creek from a hypothetical failure of the glacial moraine impounding Carver Lake near Sisters, Oregon, US Geological Survey Open File Report 87-41, US Geological Survey, Portland, Oregon, p. 48, 1987.

Mark, B. G.: Tracing tropical Andean glaciers over space and time: Some lessons and transdisciplinary implications, Global Planet. Change, 60, 101-114, 2008.

McDonald, T. C. and Langridge-Monopolis, J.: Breaching characteristics of dam failures, J. Hydraul. Eng., 110, 567-586, 1984.

Mergili, M., Schneider, D., Worni, R., and Schneider, J. F.: Glacial lake outburst floods in the Pamir of Tajikistan: Challenges in prediction and modeling. Proceedings 5th International Conference on Debris-Flow Hazards Mitigation: Mechanics, Prediction and Assessment, 14-17 June 2011, Padua, Italy, 973-982, doi:10.4408/IJEGE.2011-03.B-106. 2011.

Meyer-Peter, E. and Müller, R.: Formulas for bed-load transport, Proc. 2nd Meeting, IAHR, Stockholm, Sweden, 39-64, 1948.

Nicoletti, P. G. and Parise, M.: Seven landslides dams of old seismic origin in southeastern Sicily (Italy), Geomorphology, 46, 203$222,2002$.

Novotny, J. and Klimes, J.: Grain size distribution of soils within the Cordillera Blanca, Peru: an indicator of basic mechanical properties for slope stability evaluation, J. Mount. Sci., 11, 563-577, doi:10.1007/s11629-013-2836-9, 2014.

O’Connor, J. E., Hardison III, J. H., and Costa, J. E.: Debris Flows from Failures of Neoglacial-Age Moraine Dams in the Three Sis- ters and Mount Jefferson Wilderness Areas, Oregon, US Geological Survey Professional Paper 1606, US Geological Survey, Reston, VA, p. 93, 2001.

Osti, R., and Egashira, S.: Hydrodynamic characteristics of the Tam Pokhari Glacial Lake outburst flood in the Mt. Everest region, Nepal, Hydrol. Process., 23, 2943-2955, 2009.

Parise, M., Coe, J. A., Savage, W. Z., and Varnes, D. J.: The Slumgullion landslide (southwestern Colorado, USA): investigation and monitoring, in: Proc. International Workshop Occurrence and mechanisms of flow-like landslides in natural slopes and earthfills, edited by: Picarelli, L., 14-16 May 2003, Sorrento, 253-263, 2003.

Peng, M. and Zhang, L. M.: Breaching parameters of landslide dams, Landslides, 9, 13-31, 2012.

Pierce, M. W. and Thornton, C. I.: Predicting Peak Outflow from Breached Embankment Dams, Colorado State University, Fort Collins, Colorado, p. 45, 2010.

Sevinc, J.: The Cordillera Blanca Guide: A Unique Landscape Explained + Trips, University of Amsterdam, the Netherlands and The Mountain Institute, Lima, p. 212, 2009.

Temple, D. M., Hanson, G. J., Neilsen, M. L., and Cook, K.: Simplified breach analysis model, Part I: Background and model components, Proc. 2005 US Society on Dams Annual Meeting and Conference Salt Lake City, Utah, 6-10 June 2005, Denver, CO, 151-161, 2005.

UGRH - Unidad de Glaciologia y Recursos Hidricos: Area de Inventario de Glaciares y Lagunas, Autoridad nacional del Agua, Direcccion de Conservacion y Planeamiento de Recursos Hidricos, Huaraz, Peru, 2010.

USBR - US Bureau of Reclamation: Guidelines for defining inundated areas downstream from Bureau of Reclamation dams, Reclamation Planning Instruction 82-11, Water Resources Research Laboratory, Denver, CO, 1982.

Vilímek, V., Zapata, M. L., Klimes, J., Patzelt, Z., and Santillan, N.: Influence of glacial retreat on natural hazards of the Palcacocha Lake area, Peru, Landslides, 2, 107-115, doi:10.1007/s10346005-0052-6, 2005.

Visser, K., Hanson, G. J., Temple, D. M., Lobrecht, M., Neilsen, M. L., Funderburk, T., and Moody, H.: WinDam B Earthen Embankment Overtopping Analysis Software, US Natural Resources Conservation Service, US Department of Agriculture, Washington, D.C., 2010.

Wahl, T. L.: Uncertainty of predictions of embankment dam breach parameters, J. Hydraul. Eng., 130, 389-397, 2004.

Wahl, T. L.: Dam Breach Modeling - An Overview Of Analysis Methods, US Bureau of Reclamation, Water Resources Research Laboratory, Denver, CO, 2010.

Walder, J. S. and O'Connor, J. E.: Methods for predicting peak discharge of floods caused by failure of natural and constructed earthen dams, Water Resour. Res., 33, 2337-2348, 1997.

Wang, X., Liu, S., Gou, W., and Xu, J.: Assessment and Simulation of Glacier Lake Outburst Floods for Longbasaba and Pida Lakes, China, Mount. Res. Develop., 28, 310-317, 2008.

Wang, X., Liu, S., Ding, Y., Guo, W., Jiang, Z., Lin, J., and Han, Y.: An approach for estimating the breach probabilities of moraine-dammed lakes in the Chinese Himalayas using remotesensing data, Nat. Hazards Earth Syst. Sci., 12, 3109-3122, doi:10.5194/nhess-12-3109-2012, 2012. 
Westoby, M. J., Glasser, N. F., Brasington, J., Hambrey, M. J., Quincey, D. J., and Reynolds, J. M.: Modelling outburst floods from moraine-dammed glacial lakes, Earth Sci. Rev., 134, 137159, doi:10.1016/j.earscirev.2014.03.009, 2014.

Worni, R., Stoffel, M., Huggel, C., Volz, C., Casteller, A., and Luckman, B. Analysis and dynamic modeling of a moraine failure and glacier lake outburst flood at Ventisquero Negro, Patagonian Andes (Argentina), J. Hydrol., 444-445, 134-145, doi:10.1016/j.jhydrol.2012.04.013, 2012.
Worni, R., Huggel, C., Clague, J. J., Schaubd, Y., and Stoffel, M.: Coupling glacial lake impact, dam breach, and flood processes: A modeling perspective, Geomorphology, 224, 161-176, 2014.

Wurbs, R. A.: Dam-Breach Flood Wave Models, J. Hydraul. Eng., 113, 29-46, 1987.

$\mathrm{Xu}$, Y. and Zhang, L.: Breaching parameters for earth and rockfill dams, J. Geotech. Geoenviron. Eng., 135, 1957-1970, 2009.

Young, K. R. and Lipton, J. K.: Adaptive Governance and Climate Change in the Tropical Highlands of Western South America, Climatic Change, 78, 63-102, doi:10.1007/s10584-006-9091-9, 2006. 